\title{
Motive and Attitude to Use QR Code as an Advertising and Publicity Media: An Empirical Study
}

\author{
Seohee Kang ${ }^{1}$, Hwayeol Choi ${ }^{2}$ \\ ${ }^{1}$ Kumoh National Institute of Technology \\ ${ }^{2}$ Department of Airline Service Management, School of Business, Jeju International \\ University, South Korea \\ Corresponding author: hwayeol@hanmail.net
}

\begin{abstract}
This study investigates how the QR code, which is emerging as a new means of advertising and promoting, affects the usage motives and attitudes according to the lifestyle of smartphone users. Based on previous studies, we classified the lifestyle of smartphone users into success-oriented, social-oriented, family-oriented, impulsive-purchase, and prudent/careful-purchase types. These lifestyles have created motivation for using QR codes, and the attitudes of users can be determined accordingly. The conclusions drawn from these studies will suggest the theoretical direction of how QR codes are effective depending on the lifestyle of customers categorized by individuals or organizations who want to advertise and advertise through QR codes.
\end{abstract}

Keywords: Advertising / PR, QR code, lifestyle.

\section{Introduction}

Smartphone is a high-performance mobile phone that can freely install and operate various mobile apps (MobileApp) with a high-performance general-purpose operating system (OS) like a general PC. Convenient functions based on useroriented interface and apps have been rapidly spreading to modern people who keep pace with rapid changes. The results show that the importance of lifestyle variables on the use of new media and ad acceptance attitude were also applied to mobile advertising. In addition, it was expected that it will help to utilize mobile devices as effective marketing and advertisement channels through subsequent research on mobile advertisement messages and various types of mobile marketing messages that are adapted to lifestyle characteristics.

The spread of smartphones presented different possibilities for marketing in the 
mobile advertising market. QR code is one of the innovative technologies of smartphone. Lee and Kim (2005) used QR codes in outdoor advertising to investigate the use of $\mathrm{QR}$ codes in outdoor advertisements through contact media, contact means, post-scan route, usage information, motivation, shortcomings, attitudes, and activating the prisoners. This study suggests that QR codes create an environment that allows users to interact with customers in a limited space beyond the limit of simply delivering one-way messages. In particular, QR codes in outdoor advertising lowered the barriers to entry and were effective in real-time marketing on the move (Lee and Kim, 2005).

The purpose of this study is to analyze the motivation of consumers to use QR codes and the attitude toward the QR codes of people with various lifestyles. Based on this, we examine the possibility of QR code as a commercial communication means.

\section{Literature Review}

This study has been administered by mainly using secondary data sources. Secondary data includes various books, research works, journals and works of undergraduate and postgraduate students i.e. theses, projects, etc. These are collected from the various institutions and organizations. Urban and Regional Planning discipline and Architecture Discipline of Khulna University were the sources of those secondary data. The tactic includes analysis of the info on the case study area to spot the main constraints which impede the affordability of the actual group i.e. middle-income group during this case.

\subsection{QR Code}

As smartphones spreads, advertising and marketing using smartphones are rapidly growing and attracting attention. One of the hottest tools of interest is the QR code.

QR (Quick Response) code is a matrix method of two-dimensional bar code which was developed in 1994 by Denso Corporation of Japan and has a black and white plaid pattern. Unlike barcode, which stores only numbers, it can store various formats such as text, voice, image information, and location information. It can also display product information or link to the web site when read by a scanner. Twodimensional barcodes have emerged in order to overcome the limitations of barcodes, such as the limitation of information capacity and the uniform representation of numbers. They have four specific features: large data storage, high density data representation, data error detection and restoration, and data encryption. The QR code can easily access large amounts of information at anytime and anywhere without accessing the database with a single scan using a dedicated scanner. In addition, the QR code can be used in the offline environment such as product wrapping paper and bus stops. It can also be used in advertising. The QR code simplifies the event participation process, allowing users to participate in 
events with only one scan, unlike online, which requires a cumbersome event participation process, such as accessing URLs to participate in an event. Especially, by exposing QR code at outdoor contact through outdoor advertising, real-time marketing effect can be maximized (Jung, 2013).

$\mathrm{QR}$ code is used in conjunction with advertising to provide a basis for interacting with customers by moving away from one-way communication of simple image and product information transmission. For example, by exposing the $\mathrm{QR}$ code using the blank spaces of existing newspapers, magazines, broadcasts, and outdoor advertisements, consumers can be provided with more detailed information about the product beyond simple product advertisement or corporate image exposure. It can lead to homepage and mobile web page to implement integrated communication such as advertisement, PR, promotion, event, and CRM. In addition, it is also possible to provide the convenience of purchasing goods to customers by making it possible to connect to the purchase site immediately (Yul and Man-Soo, 2011).

QR codes that can be easily recognized by using a dedicated scanner of a smart phone without needing a separate reader due to the popularization of smart phones in recent years have been introduced to distributors, media companies, Seoul municipalities, malls, beauty industry, museum, securities company, and electronic payment. QR codes can also be transformed into design QR codes in combination with various types of designs. The design $\mathrm{QR}$ code can give users more visual stimulation, which can increase the attractiveness of the QR code and increase the effect of guiding users to access to the mobile web.
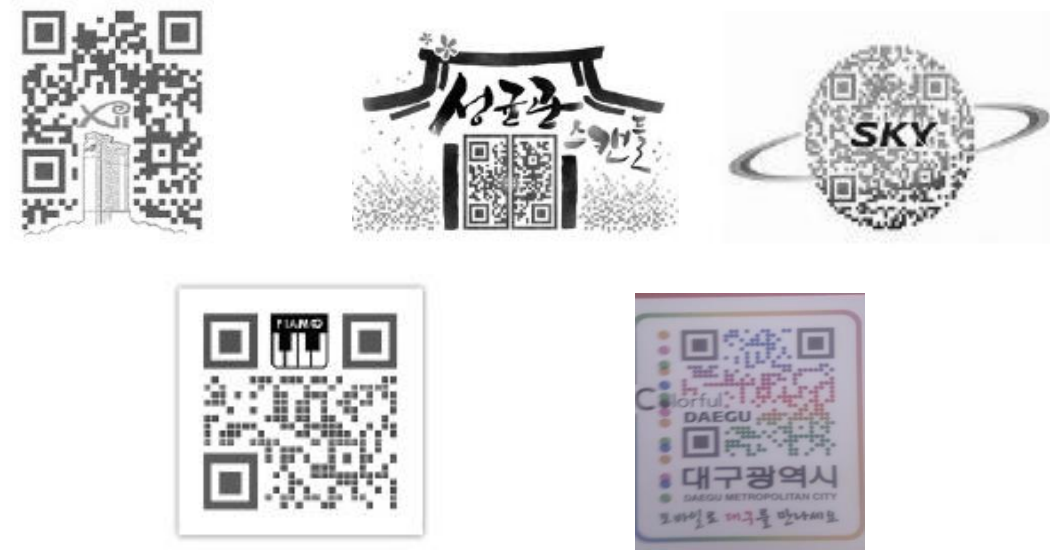

Fig. 1: Various design of QR codes.

\subsection{Lifestyle}

Lifestyle can be defined as the total of elements such as culture, resources, and symbols that make up a unique lifestyle that a particular society, group, or individual (Lazer, 1963). Engel et al. (1982) defined lifestyle as personal lifestyles 
related to the use of time and money.

Lifestyle research can be divided into macroeconomic analysis focusing on global trends of society and group, and microeconomic analysis for individual market segmentation according to research subjects (Soe-il Chae, 1992). Consumer behavior research in marketing and advertising is mainly focused on micro analysis of lifestyle characteristics for individuals or small groups. There are three methods of micro lifestyle analysis: AIO (Activities, Interest, Opinion), VALS (Values \& Lifestyles), and LOV (List of Values).

The AIO technique was developed by Wells \& Tigert (1971) and Plummer (1994) to overcome the limitations of standardized personality tests and socio-economic variables. Consumers' lifestyles were classified into daily activities (A) Interest (I) and opinion on social and personal issues $(\mathrm{O})$.

The most commercially popular technique for measuring the psychological characteristics of consumers with lifestyle is the VALS program developed by Mitchell (1983) of Stanford Research Institute in USA. VALS is an acronym for Value and Lifestyle, which is an abbreviation for demographic data and consumption statistics, as well as a value system of individuals based on individual needs and social characteristics.

On the other hand, the List of Values (LOV) technique developed by the University of Michigan's Institute is an internal value of an individual that is constantly formed in assimilating, accepting, organizing, and integrating information from the environment (Kahle, et al., 1986). Nine values are evaluated to measure lifestyle. The results of this study were summarized as follows: (1)

The lifestyle study of mobile phone users, which is the technical basis of QR advertising, is a study by Wei (2006) on Chinese consumers. In this study, they surveyed 7,000 people who live in China. They asked the types of lifestyle related to mobile phone use and directly or indirectly through surveys, and compared the differences between mobile phone use behaviour and traditional media use. Through this survey, they classified them into five types: 'realistic', 'struggle', 'value seeking', 'seeking to rise in status', and 'active professional'. Each lifestyle has a significant difference in mobile phone usage, usage frequency, media usage behavior, and advertisement exposure. These differences are directly related to education and income levels. In particular, the 'active professional' group in this study gives special suggestions by showing that they are active in advertisement exposure in all media.

In the study of internet use, which is another base of QR code advertisement, Lee and Kim (2002) conducted an off-line questionnaire surveying 700 high scholars, undergraduates, and graduate students. According to the results of analyzing the Internet users' behavior by using the self-concept, opinion leadership, acceptance of group influence, innovation, and purchase involvement as the explanatory variables of internet use along with lifestyle factors, Internet users were classified into three 
types: 'Internet-friendly', 'Internet-leading', and 'passive-use'. In contrast to the initial expectation of this study, customers were classified into simply three types, and each type showed a significant difference in Internet usage patterns.

The research of Assael (2005) was based on a lifestyle study related to general internet use behavior, and it showed that 5,000 internet users were interested in selfconsciousness, viewpoint of social issues, attitude toward success, time management, and attitude toward advertisement. As a result of classification based on 6 factors, 6 factors were different according to internet use experience. Among them, there were six types of users who use more than 20 hours: (1) Internet specialists, (2) downloaders, (3) self-developers, (4) entertainment seekers, (5) stock traders respectively.

In the study of Brengman et al. (2005), based on the interest and opinions of the Internet, six lifestyle factors were extracted such as Internet convenience, inefficiency, active, distrust, and eye shopping. In the case of Internet buyers, there were four types of potential buyers, suspicious learners, shopping enthusiasts, and business buyers. Non-buyers were classified as anxious users, negative technology learners, and adventurous users. As a result of comparing the intention of internet shopping, significant differences were found among the groups.

Yang (2004) focused on the tendency of Internet users to spread to all populations, classified the lifestyle of Internet users, and compared and analyzed the differences in attitudes toward Internet advertising among the classified groups. A total of 640 completed responses were collected by a shopping center survey for about 700 Taiwanese consumers. Using 30 items, respondents' lifestyle types were classified into 'innovative ', ' conservative ', and 'free'. These three groups showed meaningful response on the seven factors of information, materialism, consumer interest, pleasure, exaggeration, operability, and value distortion, which were derived from the conceptual dimension that constitutes the value of Internet advertising or attitude toward Internet advertising respectively.

Shim and Park (2004) analyzed advertising effects of Internet advertising, four media, cable broadcasting, and satellite broadcasting according to each type of lifestyles. Based on the results of interviews with 600 adults in Seoul and Busan, we found eight lifestyle factors and classified them with the respondents' values into 'active', 'success-oriented', 'creative-oriented', and 'sport and culture-oriented'.

Active type showed high level of interest, memory, comprehension, and purchase influence in satellite broadcasting advertisement. In the case of success-oriented type, respondents positively responded to various types of print media advertising such as newspapers, magazines, and internet, and creative-oriented shows high interest and memory in TV, radio, newspaper, and internet advertisement. Whereas, sports and culture-oriented type showed the lowest response in all effect factors. This study is meaningful in that it provides information that can be applied to advertising strategy and media strategy by expanding lifestyle research into media 
effect study.

In the study of media usage behavior of college students by Shin and Ahn (2005), media usage behavior and advertising dependency were compared and analyzed by lifestyle type. The lifestyle types measured by using 36 items were classified into three groups as 'active success seeking type', 'positive self-fulfilling type' and 'passive non-direction type'. In terms of media usage, "active pursuit type" is active in using TV, mobile phone, text message, while "positive self-fulfillment type" has the highest frequency of e-mail use and 'passive non-directional' showed the highest usage time of radio. This can be said to be the result of verifying the difference between media selection and usage according to lifestyle characteristics by type. In terms of advertising dependence, 'active success seeking type' marked significantly higher than the other two groups. 'Negative non-directional' group showed the least dependence on advertising.

The results of this study indicate that the characteristics of lifestyle are important factors in predicting mobile phone usage and internet use behavior and it shows consumers' influence on media selection and use. This shows that the effect of online-based marketing communication and advertising effect and dependence of media are significant.

Therefore, it is expected that there will be a meaningful difference between the usage motive of $\mathrm{QR}$ code and the acceptance attitude analysis according to the lifestyle type of the smartphone user who is the subject of this study.

\subsection{Usage Motive, Usage Motive}

The usage motive of QR code is selective and actively available according to the needs of users in QR code and mobile communication has many characteristics (Blumler and Katz, 1974). So, in order to explain the reason and motivation of consumers' media usage, it was analyzed by applying the framework of Uses \& Gratifications ( $U$ \& $\mathrm{G}$ ).

$\mathrm{U} \& \mathrm{G}$ focuses on the choice, acceptance, and responsiveness of media users. Its core assumption is that media users make conscious and intentional choices between many channels and content to meet their psychological needs. There is a lot of research on the use and satisfaction theory in various media, and their common conclusion is that there is an incentive to use specific media because of gratifications sought by individual users. In this process, media users try to meet psychological needs such as information seeking, entertainment, personal identity, and companionship. In addition, the motivation of the users to get satisfaction through these media usage influences the behavior of selecting the media. The study on QR code advertising is about advertisement and usage motive as well as media and usage motive. The results of this study are as follows. First, the attitude toward advertising refers to the positive or negative evaluation that people usually have about the advertisement (Lee, 2009). In the case of mass media such as TV, the 
attitude toward advertising is known to be closely related to advertisement usage behavior (Speck and Elliott, 1997), and has often been used as a variable to describe user behavior. For example, the more favorable the television advertisement is, the less the action to use the advertisement, and the more positive the response to the advertisement becomes. Conversely, the negative attitudes toward mobile advertisement will lead to advertisement usage behaviors such as deletion or subscription cancel rather than clicking or linking mobile advertisement. The attitude toward the media is the consumer's emotional response to the media in which the advertisement was placed.

\section{Research Design}

\subsection{Research Model}

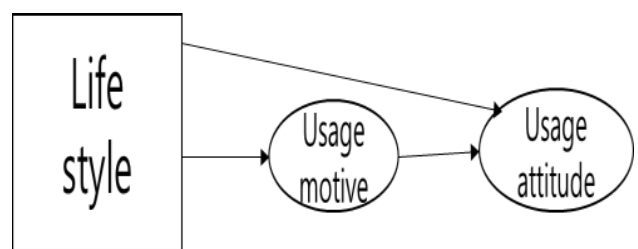

Fig. 2: Research model.

\subsection{Research Method}

The classification of lifestyles used in this study is based on the lifestyle measurement factor of the previous research (An and Kim, 2009). Some were modified to fit the situation and all were measured using the 5-point Likert scale (1 not at all, 5 - very much).

The attitude toward QR code advertisement was measured with 13 items about four factors including (1) information, (2) entertainment, (3) disturbance, and (4) interactivity. The items were like those used in the existing mobile ad attitude research, and some items were modified and used. All items were also measured using the 5-point Likert scale (1 - not at all, 5 - very similar) (Tsang and Liang, 2004). The $\mathrm{QR}$ code usage motive questions were referred to the $\mathrm{QR}$ code usage questionnaire of 'Study on Actual Use of QR Code in Outdoor Advertising' (Lee and Jung, 2011). 'To get products or related information needed', 'to participate in events or promotions',' to have fun or curiosity to get a coupon ',' to spend a free time bored ', 'to make it easier to use than the Internet and to experience a different experience', and 'to watch video advertising' are included in the questionnaire.

\subsection{Research Subjects and Analysis Methods}

The sample was extracted from the nationwide mobile phone users considering the distribution of male and female sex ratio and age group as a population. The penetration rate of smart phones by age group was $7.62 \%$ for teenagers, $35.18 \%$ for 
20s, $29.5 \%$ for 30 s, $15.1 \%$ for 40 s and $12.6 \%$ for 50 s or older. From March to June 2015, the questionnaire was distributed to 6 teenagers, 302 adults in their 20s, 13 adults in their 30s, 4 adults in their 40s, and 650 adults.

\subsection{Operational Definition and Questionnaire}

\begin{tabular}{|c|c|c|c|c|c|}
\hline \multicolumn{2}{|c|}{ Variable } & Definition & Source & Scale & $\begin{array}{c}\text { No. of } \\
\text { question }\end{array}$ \\
\hline \multirow{6}{*}{$\begin{array}{l}\text { Life } \\
\text { Style }\end{array}$} & $\begin{array}{c}\text { Success- } \\
\text { oriented type }\end{array}$ & $\begin{array}{l}\text { A group that pursues } \\
\text { social achievement } \\
\text { through self- } \\
\text { development }\end{array}$ & \multirow{6}{*}{$\begin{array}{c}\text { Research } \\
\text { on Life } \\
\text { style } \\
\text { (Yang, } \\
\text { 2004; } \\
\text { Assael, } \\
\text { 2005; Sim } \\
\text { and Park, } \\
\text { 2004; } \\
\text { Shin and } \\
\text { Ahn, } \\
\text { 2005) }\end{array}$} & \multirow{8}{*}{$\begin{array}{l}\text { Likert 5- } \\
\text { point } \\
\text { Scale }\end{array}$} & 5 \\
\hline & $\begin{array}{l}\text { Immerse- } \\
\text { purchase } \\
\text { type }\end{array}$ & $\begin{array}{l}\text { A group that has a strong } \\
\text { impulse purchase } \\
\text { tendency that is far from } \\
\text { prudent purchasing or } \\
\text { prudent buying }\end{array}$ & & & 5 \\
\hline & $\begin{array}{c}\text { Family- } \\
\text { oriented type }\end{array}$ & $\begin{array}{l}\text { A group that enjoys } \\
\text { going out with family } \\
\text { members, enjoying } \\
\text { conversation, }\end{array}$ & & & 4 \\
\hline & $\begin{array}{c}\text { Social- } \\
\text { oriented type }\end{array}$ & $\begin{array}{l}\text { A group that makes a } \\
\text { constant effort based on } \\
\text { friendly relationships } \\
\text { with others while being } \\
\text { compliant with social } \\
\text { customs }\end{array}$ & & & 5 \\
\hline & $\begin{array}{l}\text { Prudent- } \\
\text { purchase } \\
\text { type }\end{array}$ & $\begin{array}{c}\text { They are sensitive to } \\
\text { price, }\end{array}$ & & & 2 \\
\hline & $\begin{array}{l}\text { Careful- } \\
\text { purchase } \\
\text { type }\end{array}$ & $\begin{array}{l}\text { A high tendency to buy } \\
\text { with careful } \\
\text { consideration of } \\
\text { alternatives }\end{array}$ & & & 2 \\
\hline \multirow[b]{2}{*}{ Motive } & Playfulness & Curious or impatient & \multirow{2}{*}{$\begin{array}{l}\text { A Study on } \\
\text { the Actual } \\
\text { Use of QR } \\
\text { Code in } \\
\text { Outdoor }\end{array}$} & & \\
\hline & Information & $\begin{array}{l}\text { Information needed for } \\
\text { decision making } \\
\text { Access to get }\end{array}$ & & & 9 \\
\hline
\end{tabular}




\begin{tabular}{|c|c|c|c|c|}
\hline & Relationship & $\begin{array}{c}\text { Access to participate in } \\
\text { two-way } \\
\text { communication, such as } \\
\text { participation in } \\
\text { promotional events }\end{array}$ & $\begin{array}{l}\text { Advertisem } \\
\text { ent (Lee, } \\
\text { 2011) }\end{array}$ & \\
\hline \multirow{4}{*}{ Attitude } & Information & $\begin{array}{l}\text { Ability to satisfy users } \\
\text { by announcing } \\
\text { information about } \\
\text { products or services }\end{array}$ & \multirow{4}{*}{$\begin{array}{c}\text { Mobile ad } \\
\text { attitude } \\
\text { research } \\
\text { (Tsang, et } \\
\text { al., 2004; } \\
\text { Zhang \& } \\
\text { Mao, 2008) }\end{array}$} & 4 \\
\hline & $\begin{array}{c}\text { Entertainme } \\
\text { nt }\end{array}$ & $\begin{array}{l}\text { The ability of the } \\
\text { entertainment elements } \\
\text { of the message to satisfy } \\
\text { the user's aesthetic and } \\
\text { emotional needs }\end{array}$ & & 4 \\
\hline & Disturbance & $\begin{array}{l}\text { The degree to which an } \\
\text { ad is perceived as } \\
\text { irritating to a user }\end{array}$ & & 3 \\
\hline & Interactivity & $\begin{array}{l}\text { The degree of meaning } \\
\text { exchange between } \\
\text { advertisement and user }\end{array}$ & & 2 \\
\hline
\end{tabular}

\section{Results}

\subsection{Sample Characteristics}

As for the general characteristics of the sample, 158 (58.5\%) male and $103(41.5 \%)$ female were the sexes and $302(93.3 \%)$ of the 20 s were the most common. The number of students in the occupation was the highest with 306 students $(94.4 \%)$. The first questionnaire was distributed 650 copies, but the QR cord was used the most in 20 groups. This is similar to the announcement made in 2011 by ComScore, a US marketing research firm.

Table 1: General characteristics of the sample

\begin{tabular}{|c|c|c|c|c|c|c|c|}
\hline \multicolumn{2}{|c|}{ Division } & \multirow{2}{*}{$\begin{array}{c}\text { Frequency } \\
158\end{array}$} & \multirow{2}{*}{$\begin{array}{c}\text { Percent } \\
48.8\end{array}$} & \multicolumn{2}{|c|}{ Division } & \multirow{2}{*}{\begin{tabular}{|c|} 
Frequency \\
306
\end{tabular}} & \multirow{2}{*}{\begin{tabular}{|c|} 
Percent \\
94.4
\end{tabular}} \\
\hline \multirow[b]{2}{*}{ Gender } & Male & & & \multirow{4}{*}{ Occupation } & Student & & \\
\hline & Female & 166 & 51.2 & & $\begin{array}{c}\text { Office } \\
\text { Worker }\end{array}$ & 8 & 2.5 \\
\hline \multirow{2}{*}{ Age } & Teens & 6 & 1.9 & & $\begin{array}{c}\text { Government } \\
\text { Officer }\end{array}$ & 1 & .3 \\
\hline & 20th's & 302 & 93.2 & & Own & 2 & .6 \\
\hline
\end{tabular}




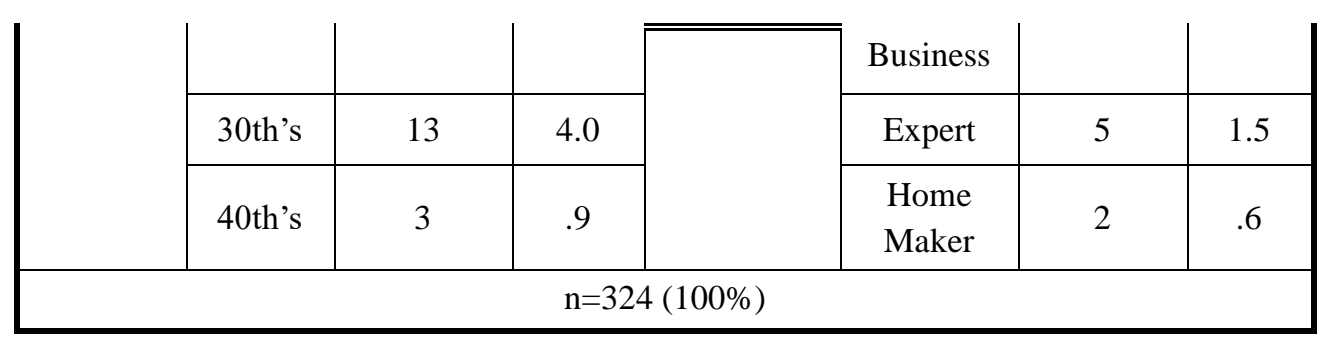

\subsection{Validity and Reliability of Measurement Items}

In this study, we conducted exploratory factor analysis, reliability analysis, and confirmatory factor analysis of the measurement items to test the validity and reliability of the measurement items before measuring the structural equation model. In order to test the validity of the items, principal component analysis was used for factor extraction and exploratory factor analysis was performed using Varimax method. Factor loading was 0.3 or higher and the cumulative variance explained was 0.5 or higher (Bagozzi and Yi, 1988). The lifestyle of the independent variables was reduced to 19 from the initial 23 items through the process of eliminating the items with the factor loading of 0.3 and the items cross-loading. The usage motive and attitude of the subordinate variable were reduced to 23 in the initial 25 questions.

The lifestyles of prudent purchasing type and careful purchasing type were reduced to a single dimension and named as prudent-careful purchasing type. The interactivity of the usage attitude was overlapped with the usage motive and the item was removed. The playfulness type, information type, and relational type of usage motivation were reduced to a single dimension and named as playfulnessinformation-relational type. The explanatory total variance of the extracted factors was $61.94 \%$ for the independent variable and $71.69 \%$ for the dependent variable, which were above the general limit of $50 \%$.

As a result of internal consistency test of items based on Cronbach's value, 0.674 $\sim 0.946$ were found to exceed the standard value of 0.6 . Therefore, it can be seen that the dimensions of the items constituting each concept of the independent variable and the dependent variable exist in a single dimension (unidimensionality).

Table 2: Result of validity and reliability

\begin{tabular}{|c|c|c|c|c|}
\hline Measuring Item & $\begin{array}{c}\text { Standardized } \\
\text { Path Coefficient }\end{array}$ & t-value & $\begin{array}{c}\text { Composite } \\
\text { Reliability }\end{array}$ & $\begin{array}{c}\text { Average } \\
\text { Variance } \\
\text { Extraction Value }\end{array}$ \\
\hline \multicolumn{5}{|c|}{ Success-oriented Type(su) } \\
\hline su1 & 0.699 & fixed & 0.7266 & 0.352267 \\
\hline su2 & 0.545 & $7.532 * * *$ & & \\
\hline
\end{tabular}




\begin{tabular}{|c|c|c|c|c|}
\hline su3 & 0.437 & $6.252 * * *$ & & \\
\hline su4 & 0.594 & $8.036 * * *$ & & \\
\hline su5 & 0.53 & $7.364 * * *$ & & \\
\hline \multicolumn{5}{|c|}{ Impulse-purchase Type(im) } \\
\hline $\operatorname{im} 2$ & 0.629 & fixed & \multirow{4}{*}{0.7778} & \multirow{4}{*}{0.469919} \\
\hline im3 & 0.763 & $10.07 * * *$ & & \\
\hline $\operatorname{im} 4$ & 0.813 & $10.348 * * *$ & & \\
\hline im5 & 0.634 & $8.873 * * *$ & & \\
\hline \multicolumn{5}{|c|}{ Family-oriented Type(fa) } \\
\hline so1 & 0.617 & fixed & \multirow{3}{*}{0.8051} & \multirow{3}{*}{$0.58172 \mathrm{c}$} \\
\hline so2 & 0.755 & $7.707 * * *$ & & \\
\hline so3 & 0.611 & $7.491 * * *$ & & \\
\hline \multicolumn{5}{|c|}{ Social-oriented Type(so) } \\
\hline fa1 & 0.761 & fixed & \multirow{3}{*}{0.8112} & \multirow{3}{*}{0.59355} \\
\hline $\mathrm{fa} 2$ & 0.831 & $11.032 * * *$ & & \\
\hline fa3 & 0.589 & $9.208 * * *$ & & \\
\hline \multicolumn{5}{|c|}{ Prudent/careful-purchase Type(frca) } \\
\hline fr1 & 0.492 & fixed & \multirow{4}{*}{0.8286} & \multirow{4}{*}{0.565729} \\
\hline fr2 & 0.547 & $7.132 * * *$ & & \\
\hline cal & 0.926 & $9.04 * * *$ & & \\
\hline $\mathrm{ca} 2$ & 0.914 & $9.04 * * *$ & & \\
\hline \multicolumn{5}{|c|}{ Attitude(Entertainment:ent) } \\
\hline ent1 & 0.887 & fixed & \multirow{4}{*}{0.9244} & \multirow{4}{*}{0.753467} \\
\hline ent2 & 0.845 & $20.061 * * *$ & & \\
\hline ent3 & 0.887 & $22.067 * * *$ & & \\
\hline ent4 & 0.852 & $20.357 * * *$ & & \\
\hline \multicolumn{5}{|c|}{ Attitude(Information:inf) } \\
\hline inf1 & 0.745 & fixed & \multirow{3}{*}{0.8622} & \multirow{3}{*}{0.610235} \\
\hline inf2 & 0.799 & $13.564 * * *$ & & \\
\hline inf3 & 0.805 & $13.676^{* * *}$ & & \\
\hline
\end{tabular}




\begin{tabular}{|c|c|c|c|c|}
\hline inf4 & 0.763 & $12.945 * * *$ & & \\
\hline & & le(Distracivi & & \\
\hline dis 1 & 0.786 & fixed & \multirow{3}{*}{0.8971} & \multirow{3}{*}{0.745273} \\
\hline dis2 & 0.956 & $17.479 * * *$ & & \\
\hline dis 3 & 0.844 & $16.44 * * *$ & & \\
\hline \multicolumn{5}{|c|}{ Attitude(Interactivity:plinre) } \\
\hline pl1 & 0.756 & fixed & \multirow{12}{*}{0.9356} & \multirow{12}{*}{0.548071} \\
\hline $\mathrm{pl} 2$ & 0.829 & $15.421 * * *$ & & \\
\hline $\mathrm{pl} 3$ & 0.798 & $14.747 * * *$ & & \\
\hline pl4 & 0.78 & $14.343 * * *$ & & \\
\hline pl5 & 0.798 & $14.739 * * *$ & & \\
\hline in1 & 0.791 & $14.58 * * *$ & & \\
\hline in 2 & 0.796 & $14.697 * * *$ & & \\
\hline in 3 & 0.834 & $15.537 * * *$ & & \\
\hline in 4 & 0.713 & $12.932 * * *$ & & \\
\hline in5 & 0.764 & $13.996 * * *$ & & \\
\hline re1 & 0.778 & $14.311 * * *$ & & \\
\hline re2 & 0.79 & $14.563 * * *$ & & \\
\hline \multicolumn{5}{|c|}{$\begin{array}{l}x^{2}=1923.551(\mathrm{df} 783), \mathrm{p}<0.000 . \mathrm{CMIN} / \mathrm{DF}=2.457 \\
760, \mathrm{AGFI}=0.723 . \mathrm{NFI}=0.779 . \mathrm{CFI}=0.855 . \mathrm{RMSEA}\end{array}$} \\
\hline
\end{tabular}

\subsection{Hypothesis Verification}

In this study, the structural equation model (SEM) was used as an analytical method for hypothesis testing. The fit of the structural equation model for path analysis was 2132.088 (df 796), $\mathrm{p}<0.000$. The results were as follows: CMIN / DF $=2.697$, GFI $=0.744, \mathrm{AGFI}=0.709, \mathrm{NFI}=0.755, \mathrm{CFI}=0.830$ and $\mathrm{RMSEA}=0.074$.

Table 3: Hypothesis verification result

\begin{tabular}{|c|c|c|c|c|c|c|}
\hline \multicolumn{2}{|c|}{ Hypothesis Division } & Estimate & S.E. & t-value & P & Adoption \\
\hline \multirow{2}{[\text{Hypothesis1]}}{$\begin{array}{c}\text { Lifestyle } \rightarrow \\
\text { Usage Motive }\end{array}$} & {$[\mathrm{H} \mathrm{1-1]}(\mathrm{su}) \rightarrow(\mathrm{ent})$} & 0.202 & 0.083 & 2.45 & 0.014 & adopted \\
\cline { 2 - 7 } & {$[\mathrm{H} \mathrm{1-2]}(\mathrm{su}) \rightarrow(\mathrm{inf})$} & 0.045 & 0.077 & 0.584 & 0.559 & reject \\
\cline { 2 - 7 } & {$[\mathrm{H} \mathrm{1-3}](\mathrm{su}) \rightarrow(\mathrm{dis})$} & 0.124 & 0.074 & 1.676 & 0.094 & reject \\
\hline
\end{tabular}




\begin{tabular}{|c|c|c|c|c|c|c|}
\hline & [H 1-4] (im) $\rightarrow$ (ent) & 0.56 & 0.094 & 5.977 & $* * *$ & adopted \\
\hline & [H 1-5] (im) $\rightarrow$ (inf) & 0.423 & 0.086 & 4.899 & $* * *$ & adopted \\
\hline & {$[$ H 1-6] (im) $\rightarrow$ (dis) } & 0.155 & 0.075 & 2.068 & 0.039 & adopted \\
\hline & [H 1-7] (so) $\rightarrow$ (ent) & 0.136 & 0.129 & 1.058 & 0.29 & reject \\
\hline & {$[\mathrm{H} 1-8]$ (so) $\rightarrow$ (inf) } & 0.272 & 0.125 & 2.172 & 0.03 & adopted \\
\hline & [H 1-9] (so) $\rightarrow$ (dis) & -0.035 & 0.116 & -0.3 & 0.765 & reject \\
\hline & {$[\mathrm{H} 1-10](\mathrm{fa}) \rightarrow(\mathrm{ent})$} & 0.035 & 0.074 & 0.476 & 0.634 & reject \\
\hline & {$[\mathrm{H} \mathrm{1-11]}$ (fa) $\rightarrow$ (inf) } & -0.014 & 0.07 & -0.199 & 0.842 & reject \\
\hline & {$\left[\begin{array}{ll}\mathrm{H} & 1-12]\end{array}\right.$ (fa) $\rightarrow$ (dis) } & -0.17 & 0.068 & -2.491 & 0.013 & adopted \\
\hline & [H 1-13] (prca) $\rightarrow($ ent $)$ & 0.244 & 0.107 & 2.276 & 0.023 & adopted \\
\hline & [H 1-14] (prca) $\rightarrow$ (inf) & 0.29 & 0.104 & 2.793 & 0.005 & adopted \\
\hline & {$[$ H 1-15] (prca) $\rightarrow($ dis $)$} & -0.025 & 0.094 & -0.268 & 0.789 & reject \\
\hline & {$[\mathrm{H} \mathrm{2-1]}$ (su) $\rightarrow$ (plinre) } & -0.027 & 0.064 & -0.419 & 0.676 & reject \\
\hline & [H 2-2] (im) $\rightarrow$ (plinre) & 0.228 & 0.08 & 2.855 & 0.004 & adopted \\
\hline Lifestyle $\rightarrow$ & [H 2-3] (so) $\rightarrow$ (plinre) & 0.1 & 0.1 & 0.999 & 0.318 & reject \\
\hline Us & [H 2-4] (fa) $\rightarrow$ (plinre) & -0.065 & 0.058 & -1.122 & 0.262 & reject \\
\hline & {$[\mathrm{H} \mathrm{2-5}]($ frca $) \rightarrow$ (plinre) } & 0.125 & 0.083 & 1.499 & 0.134 & reject \\
\hline 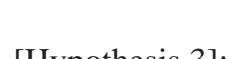 & [H 3-1] (plinre) $\rightarrow$ (ent) & 0.62 & 0.068 & 9.141 & $* * *$ & adopted \\
\hline Usage Motive $\rightarrow$ & [H 3-2] (plinre) $\rightarrow$ (inf) & 0.57 & 0.067 & 8.455 & $* * *$ & adopted \\
\hline & [H 3-3] (plinre) $\rightarrow$ (dis) & 0.01 & 0.062 & 0.16 & 0.873 & reject \\
\hline & $\begin{array}{l}2132.088(\mathrm{df} 79 \\
\text { AGFI }=0.709,1\end{array}$ & 60.00 & IIN/1 & .697 & & \\
\hline
\end{tabular}

In the lifestyle, the success-oriented type showed a positive (+) effect on the enjoyment of the usage attitude, [Hypothesis 1-1] was adopted. Impulse-purchase type among lifestyle has positive (+) influence on entertainment, information, and disturbance of usage attitude, [Hypothesis 1-4, Hypothesis 1-5, Hypothesis 1-6] was adopted. The social-oriented type of lifestyle showed positive $(+)$ influence on the information of usage attitude, [Hypothesis 1-8] was adopted. The family-oriented type of lifestyle showed a significant negative effect on the disruption of the attitude of use, [Hypothesis 1-12] was adopted. In the lifestyle, the prudent/careful purchase type was shown to have a positive (+) influence on the entertainment and 
information of the usage attitude. Impulse purchase type among lifestyle was adopted as positive influence on usage motivation. The usage motivation was shown to have a positive (+) effect on the entertainment and the information of the usage attitude.

\section{Conclusion and Discussion}

This study investigates how the QR code, which is emerging as a new means of advertising and promoting, affects the usage motives and attitudes according to the lifestyle of smartphone users. The main results and implications of the study are as follows.

First, five factors such as success - oriented type, impulsive purchasing type, family - oriented type, social - oriented type, and prudent/careful purchasing type were derived from the exploratory factor analysis of the first measurement item and the cumulative explanatory power was $61.94 \%$. In the case of the independent variable, the usage attitude was three factors of entertainment, information, and disturbance. The usage motive was derived from one factor of playfulness/information/relational type, and cumulative explanatory power was $71.69 \%$. Based on the exploratory factor analysis, the reliability analysis was conducted to analyze the reliability of the constructs. In addition, confirmatory factor analysis results show that there was intensive validity for construct validity test.

Second, we have investigated the effect of smartphone users' lifestyle on their usage motives and usage motives. Success-oriented lifestyle has a positive (+) influence on the recreation attitude. Impulse-purchase lifestyle has a positive influence on the entertainment, information, and interference of usage motive. Social-oriented lifestyle has a positive (+) influence on the information of usage motives. Family-oriented lifestyle affects the disruption of usage motive negatively (-). Prudent/careful-purchase lifestyle has positive (+) influence on the entertainment, and information quality. Impulse-purchase type lifestyle affects usage motive positively $(+)$, and usage motive affects 'amusement' and 'information' of usage attitude positively $(+)$.

The conclusions drawn from these studies will suggest the theoretical direction of how QR codes were effective depending on the lifestyle of customers categorized by individuals or organizations who want to advertise through $\mathrm{QR}$ codes.

\section{References}

Assael, H. (2005). A demographic profile of heavy Internet users and users by type of Internet usage. Journal of Advertising Research, 45(1).

Bagozzi, R.P., and Yi,Y. (1988). On the evaluation of structural equation model. Journal of Academy of Marketing Science, 16 (1). 
Brengman, M., Geuens, M., Wijters, B., Smith, S., and Swinyard, W. R. (2005). Segmenting Internet shoppers based on their web-usage-related lifestyle: A crosscultural validation. Journal of Business Research, 58.

Blumler and Katz. (1974).The use of mass-communication: current perspectives on gratifications research.

Chae Seo-il. (1992). Systematic Analysis of Korean Life Style. Journal of Consumer Studies, 3(1).

Daechun An, and Sanghoon Kim. (2009). Lifestyle Segmentation of Corporate Website Users and Its Implications. Korean Journal of Journalism \& Communication Studies, 53(1).

Engel, J., Blackwell, R., and Kollat, D. (1982). Consumer Behavior. Dryden Press: NewYork.

Kahle, L., Beatty, S., and Homer, P. (1986). Alternative measurement spproaches toconsumer values: The List of Values (LOV) and Values and Lifestyles (VALs). Journal of Consumer Research, 13.

Lee, Kyung Yul, and Kim, Sang Hoon. (2005). The Predictors of Intention of Clicking Mobile Advertising. The Korean Journal of Advertising, 16(3).

Lee Kyung Yul, and Chung Man-Soo. (2011). How QR codes are used in outdoor advertising. Korean Academy of Advertising, 8(2).

Lazer, W. (1963). Lifestyle concepts and marketing. in S. A. Greyser (ed.). Toward.

Lee, KyungYul. (2009). Normative Model of Information Processing of SMS-based Mobile Advertising. The Korean Journal of Advertising, 20(6)

Mitchell, A. (1983). The Nine American Lifestyles: Who We Are and Where We're Going. McMillan: New York. Moderator. Journal of Advertising, 11(4).

Moon-gyu Lee and Na-min Kim. (2002). Market Segmentation of the Internet Users in Korea, Korea Society of Consumer Studies, 13(4).

Myung-hee Shin and Joo-ah Ahn. (2005). Lifestyle Typology and Effects of Lifestyle on Media Use and Purchasing Behavior of University Students as Consumers. The Korean Journal of Advertising, 16(5). 
Plummer, J. T. (1974). The concept and application of lifestyle segmentation. Journal of Advertising, 19.

Suk-wook Shim and Jong-min Park. (2004). The study on the advertising effectiveness of several media and lifestyles. The Korean Journal of Advertising, $15(2)$.

Speck, P.S. and Elliott, M.T. (1997). Predictors of Advertising Avoidance in Print and Broadcasting Media. Journal of Advertising, 26(3).

Tsang, M., Ho, S., and Liang, T. (2004). Consumer attitudes toward mobile advertising: An empirical study. International Journal of Electronic Commerce, 8.

Wells, W. D., and Tigert, D. J. (1971). Activities, interests, and opinions. Journal of Advertising Research, 11.

Wei, R. (2006). Lifestyle and new media: Adoption and use of wireless communication technologies in China. New Media \& Society, 8(6).

Yong Won Jung. (2013). A Study of types of QR codes' and their effects on advertising. Journal of Korean Society of Design Science, 26 (1).

Yang, K. A. (2004).Comparison of Attitudes towards Internet advertising among lifestyle segments in Taiwan. Journal of Marketing Communications, 10.

Zhang, J., and Mao, E. (2008). Understanding the acceptance of mobile SMS advertising among young Chinese consumers. Psychology and Marketing, 25(8). 